\title{
Erratum: In defense of life sciences venture investing
}

Bruce L Booth \& Bijan Salehizadeh

Nat. Biotechnol. 29, 579-583 (2011); published online 11 July 2011; corrected after print 11 July 2011

In the version of this article initially published, the $x$ axis in Figure 1 should not have contained the category "Technology." In addition, on p. 579, col. 3, paragraph 1, the last sentence should have read "comparative realized performance" instead of "comparative performance." The errors have been corrected in the HTML and PDF versions of the article.

\section{Erratum: Donor cell type can influence the epigenome and differentiation potential of human induced pluripotent stem cells}

Kitai Kim, Rui Zhao, Akiko Doi, Kitwa Ng, Juli Unternaehrer, Patrick Cahan, Huo Hongguang, Yuin-Han Loh, Martin J Aryee, M William Lensch, Hu Li, James J Collins, Andrew P Feinberg \& George Q Daley Nat. Biotechnol. 29, 1117-1119 (2011); published online 27 November 2011; corrected after print 9 January 2012

In the version of this article initially published, the received date was incorrect. The correct received date is 17 February 2011 . The error has been corrected in the HTML and PDF versions of the article.

\section{Erratum: Move over ZFNs}

Laura DeFrancesco

Nat. Biotechnol. 29, 681-684 (2011); published online 5 August 2011; corrected after print 9 January 2012

In the version of this article initially published, Figure 1 incorrectly cites Romer et al., Plant Physiol., 2009, as the article that demonstrates "Promoter customized to bind 3 TAL effectors." It should have cited Romer et al., Proc. Nat. Acad. Sci. USA (2009). The error has been corrected in the HTML and PDF versions of the article.

\section{Corrigendum: Biotechs follow big pharma lead back into academia} Jim Kling

Nat. Biotechnol. 29, 555-556 (2011); published online 8 July 2011; corrected after print 9 January 2012

In the version of this article initially published, Gilead Biosciences was incorrectly named. The correct name is Gilead Sciences. The error has been corrected in the HTML and PDF versions of the article.

\section{Corrigendum: New models emerge for commercializing university assets}

\section{Nuala Moran}

Nat. Biotechnol. 29, 774-775 (2011); published online 8 September 2011; corrected after print 9 January 2011

In the version of this article initially published, in Box 1, the CEO at VPD is David Collier, not Michael Collier. On p. 775, second column, the University of Pennsylvania has 400 invention disclosures a year, and not, as stated, Penn State. The error has been corrected in the HTML and PDF versions of the article.

\section{Corrigendum: Drugmakers use real-world patient data to calibrate product development}

\section{Cormac Sheridan}

Nat. Biotechnol. 29, 778-779 (2011); published online 8 September 2011; corrected after print 9 January 2012

In the version of this article initially published, Medco Health Solutions' location was given as Wilmington, Delaware; it should have been Franklin Lakes, New Jersey. On p. 779, in the first paragraph, left column, UBC is said to be HealthCore's parent company. In fact, Wellpoint is HealthCore's parent company. The errors have been corrected in the HTML and PDF versions of the article. 